Thus, it seems likely that the association between atretic lesions of the gastrointestinal tract and the Waardenburg syndrome may be significant, but because of its rarity it has been overlooked.

The authors thank Professor David Klein from the Department of Ophthalmology, University of Geneva Medical School, for his helpful advice.

\footnotetext{
References

${ }^{1}$ Omenn GS, McKusick VA. The association of Waardenburg syndrome and Hirschsprung megacolon. Am J Med Genet 1979:3:217-23.

2 Nutman J, Nissenkorn I, Varsano I, Mimouni M, Goodman RM. Anal atresia and the Klein-Waardenburg syndrome. J Med Genet 1981;18:239-41.

${ }^{3}$ Feingold M, Bossert WH. Normal values for selected physical parameters: an aid to syndrome delineation. Birth Defects 1974;10:1-3.

${ }^{4}$ Goodman RM, Gorlin RJ. The malformed infant and child: an illustrated guide. New York: Oxford University Press, 1983: $422-3$.
}

${ }^{5}$ Fisch L. Deafness as part of a hereditary syndrome. $J$ Laryngol 1959;73:355-82.

6 Roux CH, Baheux G, Gaulier M, Caldera R, Soepardan L. Le syndrome de Waardenburg. Une observation familiale portant sur quatre generations et vingt-trois sujets. Ann Genet (Paris) 1970;13:125-8.

${ }^{7}$ Gray SW, Skandalakis JE. Embryology for surgeons. Philadelphia: Saunders, 1972:202-16.

${ }^{8}$ Ingalls TH, Prindle RA. Esophageal atresia with tracheoesophageal fistula: epidemiologic and teratogenic implications. $N$ Engl J Med 1949;240:987-95.

${ }^{9}$ Hasse W. Associated malformation with anal and rectal atresiae. Prog Pediatr Surg 1970;9:99-103.

${ }^{10}$ Fraser GR. The causes of profound deafness in childhood. Baltimore: Johns Hopkins University Press, 1976:90-132.

1 "Holder TM, Cloud DT, Lewis JE Jr, Pilling GP. Esophageal atresia and tracheoesophageal fistula. A survey of its members by the surgical section of the American Academy of Pediatrics. Pediatrics 1964;34:542-9.

12 Branski D, Dennis NR, Neale JM, Brooks LJ. Hirschsprung's disease and Waardenburg's syndrome. Pediatrics 1979;63:803-5.

Correspondence and requests for reprints to $\mathrm{Dr} \mathbf{R}$ Steinherz, Department of Pediatrics A, Beilinson Medical Center, Petah Tiqua 49 100, Israel.

\title{
Multifocal meningiomas in a patient with a constitutional ring chromosome 22
}

\author{
T ARINAMI*, I KONDO $\dagger$, H HAMAGUCHI $\dagger$, AND S NAKAJIMA* \\ From *Ibaraki Prefectural Colony, Higashiibaraki-gun 319-03; and the Department of Human Genetics, \\ Institute of Basic Medical Sciences, University of Tsukuba, Ibaraki-ken 305, Japan.
}

SUMMARY We report a patient with a constitutional ring chromosome 22 , in whom multifocal meningiomas were confirmed at necropsy, and discuss the relationship between the constitutional chromosome change and tumourigenesis of meningiomas in this patient.

There have been many reports of patients with partial monosomy of chromosome 22 , but the clinical features of a chromosome 22 monosomy syndrome have not been established. ${ }^{12}$ However, monosomy 22 and deletion of the distal end of the long arm of chromosome $22(22 \mathrm{q}-)$ are the commonly observed cytogenetic changes in cultured meningioma cells. ${ }^{3}$ There has been no report so far of meningiomas arising in patients with constitutional chromosome 22 anomalies.

\section{Case report}

The proband, an institutionalised mentally retarded

Received for publication 9 March 1985 Accepted for publication 19 March 1985. male, was found to have a ring chromosome 22 during a cytogenetic survey, which has been reported previously. ${ }^{4} \mathrm{He}$ was the second child of unrelated healthy parents and was born to a 32 year old father and 29 year old mother. A brother and a sister were healthy and of normal intelligence. He was delivered at term after an uneventful pregnancy, birth weight $2715 \mathrm{~g}$ and length $49 \mathrm{~cm}$. Chest and head circumferences were $28 \mathrm{~cm}$ and $30 \mathrm{~cm}$, respectively. Early development was slightly delayed and he began walking alone at 18 months. He suffered infantile tuberculosis at 2 years which was cured after treatment. His mental development was very retarded.

At the age of 20 , the proband was admitted to an institution because of an IQ of 21 . On examination, he was $158 \mathrm{~cm}$ tall $(-1.6 \mathrm{SD})$ and weighed 50 $\mathrm{kg}(-2.5 \mathrm{SD})$. His occipitofrontal circumference was $52 \mathrm{~cm}(-2.5 \mathrm{SD})$. His skull was microcephalic and dolichocephalic (cephalic index $0 \cdot 85$ ), with a flat occiput and cutis verticis gyrata. Secondary sexual development was normal. Cutaneous nodules and café-au-lait patches were not present. Other abnormalities noted were unusual facial appearance with 
full eyebrows, long eyelashes, hypertelorism (inner canthal distance $4.5 \mathrm{~cm}$, outer $9.5 \mathrm{~cm}$ ), high nasal bridge, large nose, and large ears. He also had definite kyphosis, increased reflexes, and hearing loss (fig la-c).

At 25 years of age, he had episodes of apathy, insomnia, anorexia, vomiting, mask-like facial expression, tremor of the upper extremities, instability of gait, and convulsions. These symptoms worsened and he died at 27 years.

\section{CYTOGENETIC STUDIES}

Chromosome analysis was performed on peripheral blood lymphocytes. A total of 30 cells was analysed. In all cells examined there were 46 chromosomes, but one of the $\mathrm{G}$ group chromosomes was replaced by a small ring chromosome. Using the Giemsa staining method of Seabright,${ }^{5}$ the ring chromosome was identified as originating from chromosome 22. The size and banding pattern showed that the breaks were at p12 and q13.3 (fig $2 a, b)$. Other tissues were not available for chromosome analysis.

\section{NECROPSY FINDINGS}

The brain was microcephalic (brain weight $1090 \mathrm{~g}$ ). Macroscopic examination revealed a subarachnoid multilocular cyst, approximately $6 \times 4 \times 3.5 \mathrm{~cm}$ in size, filled with slightly turbid fluid at the medullocerebellar angle, which had compressed the medulla oblongata and other surrounding brain tissues. This was the apparent cause of death. On

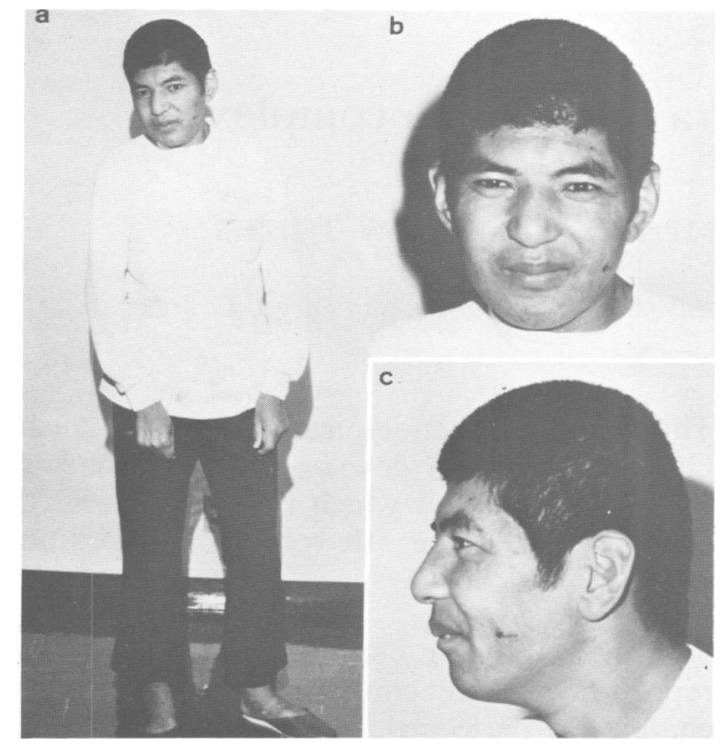

FIG $1(\mathrm{a}-\mathrm{c}) \quad$ The proband aged 23 years.

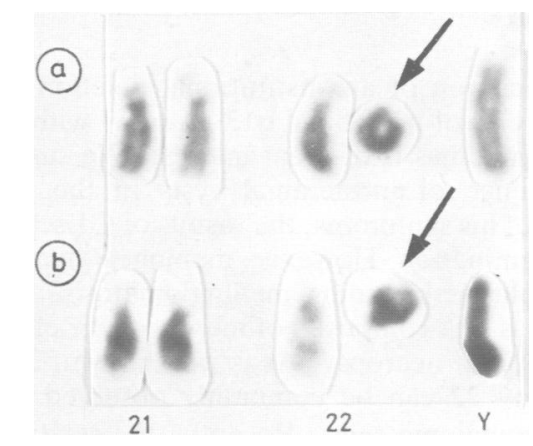

FIG 2 Partial karyotype of chromosomes 21, 22, and $Y$ from the patient, using conventional Giemsa staining (a) and trypsin-Giemsa staining (b). The arrows indicate the ring chromosome 22.

microscopic examination, the cyst wall consisted of two layers; an outer fibrovascular layer and an inner meningothelial-like cell layer. The latter showed varying thickness and a peculiar tendency to protrude into the cavity, subdividing the cyst into irregularly anastomosing partitions (fig 3a). In addition, the meningothelial-like cells showed multiple varying nodules of hyperplasia in many areas, each of which had histological patterns similar to those of fibroblastic, transitional, or angioblastic meningiomas. Degenerative features were not prominent.

Several small meningeal nodules with diameters less than $0.6 \mathrm{~cm}$ were found attached to the dura mater and the falx cerebri. Their histological picture was that of transitional meningioma with psammoma bodies (fig $3 b$ ).

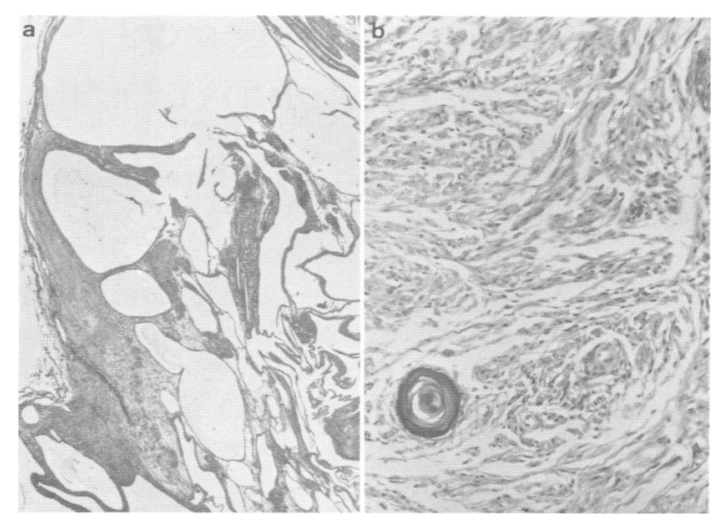

FIG 3 Microscopic morphology of multilocular portion of cyst with numerous nodules of hyperplastic fibroblastic cells (a) and typical transitional meningioma with a psammoma body (b). 


\section{Discussion}

The association of a constitutional deletion of the terminal end of $q 22$ (band $q 13 \cdot 3 \rightarrow$ qter) with multiple meningiomas is of great interest. We suspected the presence of intracranial cysts in the patient because of his symptoms, the results of CT scan, and EEG examination. However, meningeal hypoplasia and dysplasia, including meningiomatosis, and an anomalous cyst composed of meningocytic elements were found at necropsy. As is well known, 22q- or monosomy 22 can be commonly observed in cultured meningioma cells. ${ }^{3}$ Recently, the relationship between constitutional and somatic chromosomal changes in patients with retinoblastoma ${ }^{6}$ and Wilms's tumour $^{7}$ has been shown. These findings tend to support a close relationship between a partial deletion of chromosome 22 and meningeal malformations including tumours. The karyotype of the tumour cells was not investigated in our patient. However, the presence of a constitutional ring chromosome 22 , which may lack the distal end of the long arm, supports the suggestion of Zankl and Zang $^{3}$ that genetic information involved in the control of cell proliferation is located in this segment. Recently, the human homologue of the simian sarcoma virus oncogene, c-sis, has been assigned to $22 \mathrm{q} .{ }^{8}$ The proto-oncogene c-sis might be related to the genesis of meningiomas. Furthermore, these chromosome changes may be tissue specific, in the sense that they may predispose specifically to meningiomas, because necropsy revealed no neoplasia in other organs of our patient.
In conclusion, the findings described in this paper suggest that constitutional deletions of chromosome 22 may predispose to tumourigenesis of meningiomas. To confirm this, further neuropathological studies of patients with $22 \mathrm{q}-$ or monosomy 22 are required. Clinical examination for congenital anomalies and chromosome analysis should be carried out in all patients with meningiomas.

\section{References}

1 Hunter AGW, Ray M, Wang HS, Thompson DR. Phenotypic correlations in patients with ring chromosome 22. Clin Genet 1977;12:239-49.

2 Stoll C, Roth MP. Segregation of a 22 ring chromosome in three generations. Hum Genet 1983;63:294-6.

3 Zankl H, Zang KD. Cytological and cytogenetic studies on brain tumors. IV. Identification of the missing $G$ chromosome in human meningiomas as No 22 by fluorescence technique. Humangenetik 1971;14:167-79.

${ }^{4}$ Kondo I, Hamaguchi H, Nakajima S, Haneda T. A cytogenetic survey of 449 patients in a Japanese institution for the mentally retarded. Clin Genet 1980;17:177-82.

5 Seabright M. A rapid banding technique for human chromosomes. Lancet 1971;ii:971-2.

' Cavenee WK, Dryja TP, Phillips RA, et al. Expression of recessive alleles by chromosomal mechanisms in retinoblastoma. Nature 1983;305:779-84.

${ }^{7}$ Koufos A, Hansen MF, Lampkin BC, et al. Loss of alleles at loci on human chromosome 11 during genesis of Wilms' tumour. Nature 1984;309:170-2.

${ }^{8}$ Swan DC, McBride OW, Robbins KC, Keithley DA, Reddy EP, Aaronson SA. Chromosomal mapping of the simian sarcoma virus onc gene analogue in human cells. Proc Natl Acad Sci USA 1982;79:4691-5.

Correspondence and requests for reprints to $\mathrm{Dr}$ Ikuko Kondo, Department of Human Genetics, Institute of Basic Medical Sciences, University of Tsukuba, Ibaraki-ken 305, Japan.

\title{
Prenatal diagnosis and follow up of a child with a complex chromosome rearrangement
}

\author{
MARK H BOGART, CHRISTY L BRADSHAW, OLIVER W JONES, \\ AND JOHN E SCHANBERGER \\ Division of Medical Genetics, Department of Medicine, University of California, San Diego, La Jolla, \\ California 92093, USA.
}

SUMMARY A case of de novo, apparently balanced, three way exchange by translocation plus a pericentric inversion is described. The karyotype is $46, \mathrm{XX}, \mathrm{t}(6 ; 11)(\mathrm{p} 21 ; \mathrm{q} 21), \mathrm{t}(11 ; 21)$ $(\mathrm{q} 21 ; \mathrm{p} 13)$,inv(6)(p21q11) and was ascertained through second trimester amniocentesis. The structural rearrangements appear balanced.

Received for publication 20 November 1984

Revised version accepted for publication 5 February 1985.
The child was phenotypically normal at birth. Growth and motor development were normal until 30 months, at which time linear growth dropped below the 5th centile. In addition, there was delayed speech development at 2 years of age.

As far as we can determine, this is the first report of a three chromosome exchange including a pericentric inversion ascertained through genetic amniocentesis. 